\title{
Bacteria isolated from abscesses of small ruminants inspected in the semiarid region of Brazil
}

\section{Bactérias isoladas de abscessos em pequenos ruminantes inspecionados na região semiárida do Brasil}

\author{
Wellington Erasmo de Lima e Silva ${ }^{1}$; Gisele Veneroni Gouveia ${ }^{2}$; \\ Maria da Conceição Aquino de Sá3; João José de Simoni Gouveia²; \\ Rodolfo de Moraes Peixoto ${ }^{4}$; Franklin Riet-Correa ${ }^{5}$; \\ Josir Laine Aparecida Veschi'; Mateus Matiuzzi da Costa ${ }^{2 *}$
}

\begin{abstract}
Loss in the supply chain of small ruminants owing to condemnations of carcasses in the abattoirs and slaughterhouses is common in northeastern Brazil. This study aims to identify bacterial agents, including Mycobacterium spp., in the abscesses found in the postmortem analysis of the carcasses of sheep and goats bred in northeastern Brazil. Our analysis involved 679 goats and 1,838 sheep carcasses. Abscess samples were extracted and inoculated on blood agar and Lowenstein Jensen with pyruvate or glycerol for bacterial isolation. We then performed polymerase chain reaction of the hps 65 gene; samples positive for Mycobacterium spp. were subjected to DNA sequencing. Relative frequencies of abscesses in goats and sheep were 5.44 and $3.26 \%$, respectively. Microbiological analysis revealed $87.7 \%$ bacterial growth in the inoculated samples. Among these, Corynebacterium pseudotuberculosis represented $67.7 \%$ of the isolates. We observed $1.9 \%$ mycobacteria growth in the abscess samples inoculated on Lowenstein-Jensen medium. PCR of DNA extracted from abscesses samples showed amplification of $0.9 \%$ of samples. After sequencing, Mycobacterium spp. isolate was identified as $M$. novocastrense. C. pseudotuberculosis was the main agent responsible for the formation of abscesses in the examined animals, and we did not identify any species of the M. tuberculosis complex in the examined small ruminants.
\end{abstract}

Key words: Goat. Inspection. Isolation. PCR. Sheep.

\section{Resumo}

Perdas na cadeia produtiva dos pequenos ruminantes pela condenação de carcaças e vísceras são comuns nos matadouros/frigoríficos da região nordeste do Brasil. Este estudo objetivou identificar agentes bacterianos, inclusive Mycobacterium spp., no conteúdo de abscessos encontrados no exame post mortem de caprinos e ovinos criados em regiões do nordeste do Brasil. Foram inspecionados

\footnotetext{
${ }^{1}$ Prof. M.e, Faculdade de Ciências Agrárias, FACIAGRA, Araripina, PE, Brasil. E-mail: tonerasmo29@hotmail.com

2 Profs. Drs., Colegiado de Zootecnia, Universidade Federal do Vale do São Francisco, UNIVASF, Petrolina, PE, Brasil. E-mail: giseleveneroni@yahoo.com.br; joao.gouveia@univasf.edu.br; mateus.costa@univasf.edu.br

${ }^{3}$ Discente do Curso de Doutorado em Biotecnologia, Rede Nordeste de Biotecnologia, RENORBIO, Universidade Federal da Bahia, UFBA, Salvador, BA, Brasil. E-mail: ceicazoo@hotmail.com

${ }^{4}$ Prof. Dr., Colegiado de Zootecnia, Instituto Federal do Sertão Pernambucano, IF SERTÃO, PE, Petrolina, PE, Brasil. E-mail: rmpeixoto.vet@gmail.com

${ }^{5}$ Prof. Dr., Centro de Saúde e Tecnologia Rural, Universidade Federal de Campina Grande, UFCG, Patos, PB, Brasil. E-mail: franklin.riet@pq.cnpq.br

${ }^{6}$ Prof $^{\mathrm{a}} \mathrm{Dr}^{\mathrm{a}}$, Embrapa Semiárido, Petrolina, PE, Brasil. E-mail: josir.veschi@embrapa.br

* Author for correspondence
} 
no exame post mortem 679 caprinos e 1.838 ovinos. Para o isolamento bacteriano as amostras foram cultivadas em meio Agar Sangue e Lowenstein Jensen contendo piruvato ou glicerol. Além do cultivo, foi realizada identificação molecular para Mycobacterium spp. pela técnica de Reação em Cadeia de Polimerase (PCR) em que foram utilizados primers que amplificam fragmentos de parte do gene hsp65. As amostras positivas para micobactérias foram submetidas ao sequenciamento de DNA. As frequências relativas de abscessos em caprinos e ovinos foram de 5,44\% (37/679) e 3,26\% (60/1.838), respectivamente. No exame microbiológico, utilizando o meio Ágar Sague, observou-se crescimento bacteriano em 87,7\% (93/106) das amostras cultivadas. Destes, o Corynebacterium pseudotuberculosis representou 67,7\% (63/93) dos isolados. Do cultivo em meio Lowenstein Jensen foram isolados micobactérias em 1,9\% (2/106) das amostras de abscessos e, na PCR com DNA extraído direto das amostras de abscessos, observou-se amplificação em $0,9 \%$ (1/106) das amostras. No sequenciamento o isolado de Mycobacterium spp. foi confirmado como M. Novocastrense. C. pseudotuberculosis foi o principal agente responsável pela formação de abscessos nos animais avaliados e não foi identificada nenhuma espécie do complexo M. tuberculosis nos pequenos ruminantes inspecionados.

Palavras-chave: Caprino. Inspeção. Isolamento. Ovino. PCR.

\section{Introduction}

Breeding of sheep and goats is an important economic activity in the semiarid region of Brazil. This is possible because of the resistance of animals to the climate of this region, which is usually very warm, dry, and accompanied with long periods of drought (SARDI et al., 2012). Animals are usually bred in small or medium-sized rural properties, with simple stockyards, lacking sanitary handling of the animals, which makes prevention and control of infectious and parasitic diseases impossible (ALENCAR et al., 2010).

Infectious diseases cause losses in the small ruminants' production chain. Postmortem of carcasses and offal revealed the presence of abscesses, which are mainly caused by bacterial infection (RADOSTITS et al., 2002).

Among the microorganisms, which are responsible for the condemnation of carcasses at slaughterhouses, we focus on those of the Mycobacterium tuberculosis complex. These are especially relevant for the losses they cause to animal production and for the risk they cause to public health (CVETNIC et al., 2007; GUMI et al., 2012). Tuberculosis in sheep and goats is caused by $M$. bovis, and less frequently by $M$. tuberculosis and M. caprae (BEZOS et al., 2010; PIGNATA et al., 2009).

Animals affected by tuberculosis may not present visible clinical signs, but exhibit progressive weight loss and peripheral lymph nodes infarction (necrosis) (RIET-CORREA et al., 2007). Macroscopic analysis revealed that a lymph node is a firm, white, grey, or yellow colored dry nodule, with a caseous and necrotic center. Moreover, calcification, which is commonly found in lesions, was detected by a gritty sound upon incision in the postmortem examination of affected animals (JONES et al., 2000). In addition, postmortem findings revealed similar results for other small ruminant diseases in slaughterhouses. For example, caseous lymphadenitis, caused by Corynebacterium pseudotuberculosis, is characterized by yellowishgreen or whitish-yellow abscess formation, with the consistency varying from purulent to caseous (SOUZA et al., 2011).

Hence, the study aims to identify bacterial agents, including Mycobacterium spp., in the abscess of sheep and goats after postmortem examination.

\section{Materials and Methods}

\section{Animals and abscesses sampling}

In this study, we inspected 2,517 animals (679 goats, 1,838 sheep), slaughtered in abattoirs of rural regions of Petrolina (State of Pernambuco) and Juazeiro (State of Bahia), Brazil. Among these animals, 97 showed abscess formation in the entrails (internal organs) and/or in the whole carcasses 
(among these, nine animals presented abscesses in several different organs). We collected 106 abscess samples from these animals for study. The samples were subjected to microbiological and molecular analyses.

The samples were collected during the process of evisceration of the animals. These samples were collected in two different sampling boxes: a sterile box, which had been refrigerated; and a bottle containing 10\% buffered formalin. After collection, samples were taken to the laboratory for analysis.

\section{Bacterial cultivation}

For the cultivation of Mycobacteria, the samples were decontaminated according with Petrof method, as described by Quinn et al. (1994). After this, $0.1 \mathrm{~mL}$ of sample was grown in LowensteinJensen medium with pyruvate and LowensteinJensen medium with glycerol. The samples were then stored at $37^{\circ} \mathrm{C}$ for 120 days. Observations were recorded weekly.

For the differential identification of the bacteria, samples were grown in 5\% sheep blood agar and stored for $48 \mathrm{~h}$ at $37{ }^{\circ} \mathrm{C}$. Isolated bacterial colonies were identified by Gram staining and sugars fermentation tests (glucose, and maltose), esculine test, nitrate reduction, DNAse and urease tests (QUINN et al., 1994).

\section{DNA extraction}

DNA was extracted from the tissues where the abscesses were present, using the following protocol: samples were macerated in liquid nitrogen. After this, $200 \mathrm{mg}$ of sample was transferred to a microtube and $800 \mu \mathrm{L}$ of extraction solution (50 mM Tris $\mathrm{HCl}$ pH 8; 25 mM EDTA; 400 mM NaCl; $100 \mu \mathrm{L}$ SDS $10 \%$ and $0.2 \mathrm{mg} \mathrm{K}$-proteinase) was added. The mixture was then homogenized and incubated at $65^{\circ} \mathrm{C}$ for $5 \mathrm{~h}$

After incubation, the sample was transferred into two microtubes, and $442 \mu \mathrm{L} \mathrm{NaCl} 2 \mathrm{M}$ was added to each tube. The microtubes were then stored at $4{ }^{\circ} \mathrm{C}$ for $15 \mathrm{~min}$. After this, $450 \mu \mathrm{L}$ from each tube was transferred to a new microtube containing $50 \mu \mathrm{L}$ sodium acetate $(3 \mathrm{M})$. Then DNA was precipitated using $1 \mathrm{~mL}$ of iced absolute ethanol. Microtubes were lightly shaken and centrifuged at $14,000 \mathrm{~g}$ for $15 \mathrm{~min}$. Supernatant was discarded and $200 \mu \mathrm{L}$ of $70 \%$ ethanol was added. The tubes were again centrifuged at 14,000 $\mathrm{g}$ for $5 \mathrm{~min}$ and the supernatant was discarded. The microtubes were left to dry and the material was suspended in $500 \mu \mathrm{L}$ of TE $(10$ $\mathrm{mM}$ Tris/HCL pH 8 and $1 \mathrm{mM}$ EDTA pH 8) and left at $4{ }^{\circ} \mathrm{C}$ overnight.

Next, $500 \mu \mathrm{L}$ of chloroform-isoamylic alcohol (24:1) was added to the material and the tubes were shaken by inversion. After this, the tubes were centrifuged at $1700 \mathrm{~g}$ for $10 \mathrm{~min}$, and the first phase of the material was collected in a new tube. DNA was precipitated using $1 \mathrm{~mL}$ frozen absolute ethanol. Tubes were lightly shaken and centrifuged at 14,000 $g$ for $15 \mathrm{~min}$. The supernatant was discarded and the tubes were left to dry for $15 \mathrm{~min}$. In the end, DNA was re-suspended in $50 \mu \mathrm{L} \mathrm{TE}+2.5 \mu \mathrm{L}$ RNAse and left to dry for $20 \mathrm{~min}$ at $37^{\circ} \mathrm{C}$.

The DNA of the bacterial colonies were extracted from the samples inoculated in Lowenstein-Jensen medium using the following method: the sample was inactivated by heat and left for $10 \mathrm{~min}$ at 80 ${ }^{\circ} \mathrm{C}$; then 10 colony forming units (CFU) were added to $300 \mu \mathrm{L}$ TE (Tris EDTA). After this, $70 \mu \mathrm{L}$ of $10 \%$ SDS was added and the sample was quickly shaken using a vortex. Then, $100 \mu \mathrm{L}$ of $\mathrm{NaCl}_{2} 5 \mathrm{M}$ and $80 \mu \mathrm{L} \mathrm{CTAB} / \mathrm{NaCl}$ were added and the sample was incubated at $65{ }^{\circ} \mathrm{C}$ for $10 \mathrm{~min}$. Then, $700 \mu \mathrm{L}$ of chloroform-isoamylic alcohol (24:1) was added and the sample was homogenized by inversion and centrifuged at $11,759 \mathrm{~g}$ for $5 \mathrm{~min}$. The first phase was transferred to a new tube, and $450 \mu \mathrm{L}$ of isopropanol was added and left overnight. The following day, the sample was centrifuged at 11,750 $g$ for $15 \mathrm{~min}$. The superficial layer was discarded and $500 \mu \mathrm{L}$ of $70 \%$ ethanol was added. The sample was again centrifuged at $11,750 \mathrm{~g}$ for $10 \mathrm{~min}$. The 
superficial layer was again discarded and the sample was left to dry for $15 \mathrm{~min}$. The pellet was suspended in $80 \mu \mathrm{L} \mathrm{TE}(\mathrm{pH} 8.0)$ and was left for $1 \mathrm{~h}$ at $65^{\circ} \mathrm{C}$, and then stored at $-20^{\circ} \mathrm{C}$.

The sample was analyzed by $1 \%$ agarose-gel electrophoresis to determine the quality of the extracted DNA.

\section{PCR for the detection of Mycobacterium spp.}

DNA derived from the bacterial colonies of abscess samples seeded in Lowenstein-Jensen medium was analyzed for Mycobacterium spp. identification by PCR using Tb 11 ("ACCAACGATGGTGTGTCCAT) and Tb 12 (CTTGTCGAACCGCATACCCT) primers, as described in the literature (TELENTI et al., 1993). These primers amplified a $439 \mathrm{bp}$ fragment of the hsp 65 gene. PCR was performed with a final volume of $20 \mu \mathrm{L}$ containing: enzyme buffer $1 \mathrm{X}, 1.25 \mathrm{mM}$ of $\mathrm{MgCl}_{2}, 0.25 \mathrm{mM}$ of each dNTP, $0.125 \mu \mathrm{M}$ of each primer, 2.5 units of Taq DNA polymerase, and 5 $\mu \mathrm{L}$ genomic DNA. The amplification reaction was performed with an initial denaturation at $94^{\circ} \mathrm{C}$ for 10 min, followed by 45 cycles of denaturation at $94^{\circ} \mathrm{C}$ for $1 \mathrm{~min}$, annealing at $60^{\circ} \mathrm{C}$ for $1 \mathrm{~min}$, and extension at $72{ }^{\circ} \mathrm{C}$ for $1 \mathrm{~min}$. After these cycles, the amplified product was submitted for a final extension at $72{ }^{\circ} \mathrm{C}$ for 10 minutes. The products were then analyzed in $1.5 \%$ agarose gel and visualized under UV light.

\section{DNA sequencing}

The PCR products were purified using a purification kit (Quick Gel Extraction \& PCR Purification COMBO Kit-Invitrogen) and were sequenced using the automatic sequencer ABI-PRIM 3100 Genetic Analyser by the Sanger method.
The electropherograms were analyzed using PHRED software to check the quality of the sequences. Sequences with PHRED quality scores $\geq 20$ (EWING et al., 1998) were analyzed using the nucleotide blast option, nucleotide collection database, of the Basic Local Align Sequence Tool $(<$ http: //blast.ncbi.nlm.nih.gov/Blast.cgi $>$ ) to confirm the species.

\section{Histopathologic examination}

Fragments of the lesions were dehydrated in ethylic alcohol at progressively increasing concentration, diaphanized in xylene, and embedded in paraffin blocs. The blocs were later cut into $4 \mu \mathrm{m}$ thick blocs using a microtome. Slides were later stained using hematoxylin-eosin (PROPHET et al., 1992) and Ziehl-Neelsen staining.

\section{Results}

The distribution of the animals examined at the postmortem inspection showed greater number of abscesses in goats (Table 1). Bacteriologic analysis of abscesses from samples seeded on LowensteinJensen medium revealed that $1.9 \%(2 / 106)$ of the isolated bacterial colony was characterized as acidalcohol resistant bacillus (AARB) and confirmed as Mycobacterium spp. using PCR. The two isolates were from abscesses found in the liver and in the esophagus of a goat and a sheep, respectively. These isolates were observed after 4 weeks growth in Lowenstein-Jensen Medium with sodium pyruvate. The sequencing of these isolates indicated that they belong to $M$. novocastrense species. This analysis showed a total score of 654 , e-value of 0.0 , and identity of $97 \%$. 
Table 1. Distribution of sheep and goats examined at postmortem inspection and absolute and relative frequency of animals with abscesses.

\begin{tabular}{cccc}
\hline \multirow{2}{*}{ Animals } & \multirow{2}{*}{ Number of inspected animals } & \multicolumn{2}{c}{ Animals with abscesses } \\
\cline { 3 - 4 } & 679 & 37 & Relative frequency (\%) \\
\hline Goats & 1.838 & 60 & 5.44 \\
Sheep & 2.517 & 97 & 3.26 \\
Total & & & 3.85 \\
\hline
\end{tabular}

Corynebacterium pseudotuberculosis was also found in the samples that were isolated and identified as Mycobacterium spp., as it was cultivated on blood agar. The microorganisms isolated from blood agar medium are presented in Table 2. A total of 93 out of 106 cultivated specimens were bacteria. Among the isolated species, C. pseudotuberculosis represented $59.4 \%(63 / 106)$ of the isolates, followed by Bacillus spp. (11.3\%), Pseudomonas spp. (5.7\%), Staphylococcus spp. (4.7\%), Micrococcus spp. (2.8\%), Edwardsiella spp. (2.8\%), and Shigella spp. $(0.9 \%)$.

Molecular analysis of DNA extracted from abscesses revealed that $0.9 \%(1 / 106)$ of the sample was characterized as Mycobacterium spp. (the positive sample was from abscess on the ribs region of a sheep). The sequencing of this isolate did not show high quality (Phred value $<20$ ) product and hence could not help in the distinction of the species.

Histopathological analysis of positive specimens in cultivation for Mycobacteria showed areas with calcium salt deposition surrounded by areas of necrosis with large colonies, which is typical of caseous lymphadenitis. Besides this, we could not observe the presence of the alcohol-acid resistant bacillus on Ziehl Neelsen stain.

\section{Discussion}

The results show that the relative frequency of abscesses in goats was higher compared to sheep (Table 1). Andrade et al. (2012) found similar results in their study on external abscesses in sheep and goats from other regions of northeastern Brazil.
The identification of animals with abscesses at slaughtering houses causes significant economic loss because of the contamination of carcasses and the lack of sanitary barriers. Besides this, some of the bacteria, which are causative agents of these lesions may present high risk to the public health (COSTA, 2002; GUMI et al., 2012). The high frequency of abscesses in small ruminants bred in the semiarid region of Brazil may be explained by the lack of sanitary handling techniques and by local factors, such as the presence of many plants of the family Cactaceae in the pasturing areas, which may hurt the animal skin (LANGENEGGER et al., 1991; PINHEIRO et al., 2000).

Two abscess samples grown on selective medium revealed the presence of Mycobacterium spp., which was also confirmed by PCR. However, PCR of DNA extracted from abscesses showed the presence of another isolate. Previous studies reported low prevalence of Mycobacterium spp. on sheep and goat tissues slaughtered in Ethiopia (KASSA et al., 2012).

Bacteriologic analysis and PCR of DNA extracted from abscesses showed contradictory results, as samples that were positive for bacterial growth were later negative at PCR. PCR inhibitors in clinical samples may justify the false-negative results, which were shown using this technique (MICHEL et al., 2010).

Sequencing of Mycobacterium spp. positive samples isolated from abscesses showed microorganisms homologous to $M$. novocastrense. The effect of $M$. novocastrense on the health of small ruminants is still unknown. However, $M$. 
novocastrense is isolated from granulomatous lesions of humans and confirmed by sequencing (SHOJAEI et al., 1997). The DNA from PCRpositive samples extracted from abscesses did not have PHRED quality and therefore was not used for BLAST alignment; thus, we can only say that it belongs to the genus of Mycobacterium spp.

Among other microorganisms identified in bacterial culture, C. pseudotuberculosis was found at a higher frequency. Several previous studies have shown the occurrence of caseous lymphadenitis in sheep and goats in Brazil (ANDRADE et al., 2012; PINHEIRO et al., 2000; SEYFFERT et al., 2010; SOUZA et al., 2011). Samples analyzed of infarcted lymph nodes presented prevalence of $74.5 \%$ of $C$. pseudotuberculosis, which is similar to our findings (SOUZA et al., 2011). These findings show the relevance of caseous lymphadenitis for the breeding of small ruminants in the semiarid region of Brazil, qualifying it as the main cause of contamination of carcasses and entrails in the region.

The highest frequency of abscesses found at postmortem examination of carcasses was in the lungs (Table 2). Granulomatous lesions in the respiratory tract of small ruminants are common and may be an important source of contamination of the flock through the production of infected aerosol (BAIRD; FONTAINE, 2007; FONTAINE; BAIRD, 2008; MELO et al., 2012). These lesions may also be found in mesenteric lymph nodes, sub mandibular lymph nodes, spleen, tunicas serosas, and utero (BENESI et al., 2008; NEILL et al., 1994).

Histopathologic analyses showed typical features of caseous lymphadenitis. Besides this, we could not observe the presence of the alcoholacid resistant bacillus on Ziehl Neelsen stain. This confirmed the results of the cultivation in blood agar, where isolates of $C$. pseudotuberculosis were found as responsive for the macroscopic lesions seen in the postmortem examination of the animals. Histologic lesions with necrotic central area made of concentric layers, with large bacterial colonies and points of mineralization, surrounded by a band of inflammatory infiltrate with macrophage are common in C. pseudotuberculosis lesions, but they cannot be considered pathognomonic as they are common in lesions caused by other pyogenic organisms and with tuberculosis (SOUZA et al., 2011).

\section{Conclusion}

No species of the M. tuberculosis complex were found in abscesses of sheep and goats examined in the northeastern region of Brazil. M. novocastrense was detected, but this species does not represent a risk for the health of small ruminants.

The results of the postmortem examination revealed that goats are quite susceptible to infections, causing abscesses in carcasses and entrails, mainly liver and lungs. C. pseudotuberculosis, responsible for caseous lymphadenitis in small ruminants, was the main causative agent of the abscesses found in the examined sheep and goats carcasses, stressing out the relevance of the organization of the sanitary inspection system, considering the relevance of these bacteria for public health.

\section{Acknowledgments}

The authors thank CAPES and FACEPE for the granting scholarships. 


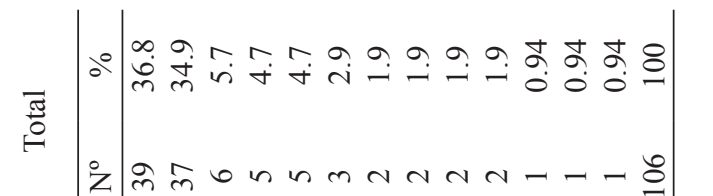

a

ㄴ. 纺

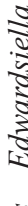

$\partial$

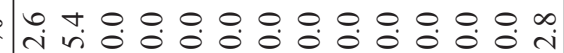

\& $\quad$ व के

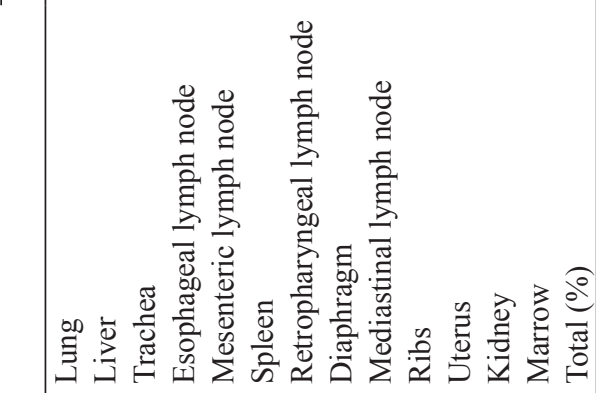

\section{References}

ALENCAR, S. P.; MOTA, R. A.; COELHO, M. C. O. C.; NASCIMENTO, S. A.; ABREU, S. R. O.; CASTRO, R. S. Perfil sanitário dos rebanhos caprinos e ovinos no sertão de Pernambuco. Ciência Animal Brasileira, Goiânia, v. 11, n. 1, p. 131-140, 2010.

ANDRADE, J. S. L.; AZEVEDO, S. S.; TELES, J. A. A.; HIGINO, S. S. S.; AZEVEDO, E. O. Occurrence and risk factors associated with the Corynebacterium pseudotuberculosis infection in sheep and goats from the semiarid region of the Paraiba state, northeastern, Brazil. Pesquisa Veterinária Brasileira, Rio de Janeiro, v. 32, n. 2, p. 116-120, 2012.

BAIRD, G. J.; FONTAINE, M. C. Corynebacterium pseudotuberculosis and its role in ovine caseous lymphadenitis. Journal of Comparative. Pathology, Liverpool, v. 137, n. 4, p. 179-210, 2007.

BENESI, F. J.; PINHEIRO, S. R.; MAIORKA, P. C.; SAKAMOTO, S. M.; ROXO, E.; BENITES, N. R.; BIRGEL JUNIOR, E. H.; GREGORY, L. Case report: tuberculosis in a goat (Capra hircus). Arquivos do Instituto Biológico, São Paulo, v. 75, n. 2, p. 217-220, 2008.

BEZOS, J.; DE JUAN, L.; ROMERO, B.; ALVAREZ, J.; MAZZUCCHELLI, F.; MATEOS, A.; DOMÍNGUEZ, L.; ARANAZ,A.Experimentalinfection with Mycobacterium caprae in goats and evaluation of immunological status in tuberculosis and paratuberculosis co-infected animals. Veterinary Immunology Immunopathology, New York, v. 133, n. 2-4, p. 269-275, 2010.

COSTA, L. F. M. Corynebacterium pseudotuberculosis, the etiological agent of the caseous lymphadenitis in goats. Revista de Ciências Médicas e Biológicas, Salvador, v. 1, n. 1, p. 105-115, 2002.

CVETNIC， Z.; KATALINIC-JANKOVIC， V.; SOSTARIC, B.; SPICIC, S.; OBROVAC, M.; MARJANOVIC, S.; BENIC, M.; KIRIN, B. K.; VICKOVIC, I. Mycobacterium caprae in cattle and humans in Croatia. International Journal of Tuberculosis and Lung Disease, Paris, v. 11, n. 6, p. 652-658, 2007.

EWING, B.; HILLIER, L.; WENDL, M. C.; GREEN, P. Basecalling of automated sequencer traces using phred. I. Accuracy assessment. Genome Research, Cold Spring Harbor, v. 8, n. 3, p. 175-185, 1998.

FONTAINE, M. C.; BAIRD, G. J. Caseous lymphadenitis. Small Ruminant Research, Little Rock, v. 76, n. 1, p. 4248, 2008.

GUMI, B.; SCHELLING, E.; BERG, S.; FIRDESSA, R.; ERENSO, G.; MEKONNEN, W.; HAILU, E.; MELESE, E.; HUSSEIN, J.; ASEFFA, A.; ZINSSTAG, J. Zoonotic 
transmission of tuberculosis between pastoralists and their livestock in South-East Ethiopia. EcoHealth, Ney York, v. 9, n. 2, p. 139-149, 2012.

JONES, T.C; HUNT, R. D.; KING, N. W. Patologia veterinária. $6^{\text {th }}$ ed. São Paulo: Manole Ltda, 2000. 1415 p.

KASSA, G. M.; ABEBE, F.; WORKU, Y.; LEGESSE, M.; MEDHIN, G.; BJUNE, G.; AMENI, G. Tuberculosis in goats and sheep in Afar Pastoral Region of Ethiopia and isolation of Mycobacterium tuberculosis from goat. Veterinary Medicine International, New York, v. 2012, p. 1-8, 2012.

LANGENEGGER, J.; LANGENEGGER, C. H.; SCHERER, P. O. Prevalência e diagnóstico comparativo da linfadenite caseosa em caprinos do Estado do Rio de Janeiro. Pesquisa Veterinária Brasileira, Rio de Janeiro, v. 11, p. 31-34, 1991.

MELO, L. E. H.; MOTA, R. A.; MAIA, F. C. L.; FERNANDES, A. C. C.; SILVA, T. I. B.; LEITE, J. E. B.; BAPTISTAFILHO, L. C. F.; RAMOS, C. A. N. Occurrence and characterization of tuberculosis in dairy goats bred in the state of Pernambuco, Brazil. Pesquisa Veterinária Brasileira, Rio de Janeiro, v. 32, n. 9, p. 831-837, 2012.

MICHEL, A. L.; MÜLLER, B.; VAN HELDEN, P. D. Mycobacterium bovis at the animal-human interface: A problem, or not? Veterinary Microbiology, Ames, v. 140, n. 3-4, p. 371-381, 2010.

NEILL, S. D.; POLLOCK, J. M.; BRYSON, D. B.; HANNA, J. Pathogenesis of Mycobacterium bovis infection in cattle. Veterinary Microbiology, Ames, v. 40, n. 1-2, p. 41-52, 1994.

PIGNATA, W. A.; ALVES, C. J.; AZEVEDO, S. S.; DANTAS, A. F. M.; GOMES, A. A. B.; REMÍGIO, F. R.; LIMA, F. S.; MOTA, P. M. P. Prevalence for caprine tuberculosis in semi-arid of Paraíba. Pesquisa Veterinária Brasileira, Rio de Janeiro, v. 29, n. 7, p. 526-532, 2009.

PINHEIRO, R. R.; GOUVEIA, A. M. G.; ALVES, F. S. F.; HADDAD, J. P. A. Epidemiological aspects of the raising goat in Ceará State, Brazil. Arquivo Brasileiro de Medicina Veterinária e Zootecnia, Belo Horizonte, v. 52, n. 5, p. 534-543, 2000.

PROPHET, E. B.; MILLS, B.; ARRINGTON, B.; SOBIN, L. H. Laboratory methods in histotechnology. Washington: Armed Forces Institute of Pathology, 1992. $279 \mathrm{p}$.
QUINN, J. P.; CARTER, M. E.; MARKEY, B.; CARTER, G. R. Mycobacterium species. In: .(Ed.). Clinical veterinary microbiology. London: Wolfe Publishing, 1994. cap. 12, p. 156-69.

RADOSTITS, O. M.; GAY, C. C.; BLOOD, D. C.; HINCHCLIFF, K. W. Veterinary clinic: a treatise on the diseases of cattle, sheep, pigs, goats and horses. $9^{\text {th }} \mathrm{ed}$. Rio de Janeiro: Guanabara Koogan, 2002. 1737 p.

RIET-CORREA, F.; SCHILD, A. L.; LEMOS, R. A. A.; BORGES, J. R. J. Doenças de ruminantes e equideos. 3. ed. Santa Maria: Pallotti, 2007. v. 1, 425 p.

SARDI, S. I.; SENA, G. S. R.; CAMPOS, G. S.; SANTOS, G. R.; MAIA NETO, A. L.; AVILA, L. N. Occurrence of small ruminant lentivirus in the semi-arid of Bahia and the productivity profile of the region. Ciência Animal Brasileira, Goiânia, v. 13, n. 4, p. 494-503, 2012.

SEYFFERT, N.; GUIMARÃES, A. S.; PACHECO, L. G.; PORTELA, R. W.; BASTOS, B. L.; DORELLA, F. A.; HEINEMANN, M. B.; LAGE, A. P.; GOUVEIA, A. M.; MEYER, R.; MIYOSHI, A.; AZEVEDO, V. High seroprevalence of caseous lymphadenitis in Brazilian goat herds revealed by Corynebacterium pseudotuberculosis secreted proteins-based ELISA. Research in Veterinary Science, London, v. 88, n. 1, p. 50-55, 2010.

SHOJAEI, H.; GOODFELLOW, M.; MAGEE, J. G.; FREEMAN, R.; GOULD, F. K.; BRIGNALL, C. G. Mycobacterium novocastrense sp. nov., a rapidly growing photochromogenic Mycobacterium. International Journal of Systematic Bacteriology, Ames, v. 47, n. 4, p. 1205-1207, 1997.

SOUZA, M. F.; CARVALHO, A. Q.; GARINO JÚNIOR, R.; RIET-CORREA, F. Caseous lymphadenitis in slaughtered hair sheep in northeastern Brazil. Pesquisa Veterinária Brasileira, Rio de Janeiro, v. 31, n. 3, p. 224230, 2011.

TELENTI, A.; MARCHESI, F.; BALZ, M.; BALLY, F.; BOTTGER, E. C.; BODMER, T. Rapid identification of mycobacteria to the species level by polymerase chain reaction and restriction enzyme analysis. Journal of Clinical Microbiology, Washington, v. 31, n. 2, p. 175178, 1993. 